\title{
How Deltamethrin Produces Oxidative Stress in Liver and Kidney
}

\author{
Barbara Nieradko-Iwanicka*, Andrzej Borzęcki \\ Chair and Department of Hygiene, Medical University of Lublin, \\ Radziwiłłowska 11, 20-080 Lublin, Poland
}

Received: 23 September 2015

Accepted: 16 February 2016

\begin{abstract}
Deltamethrin (DEL) is a synthetic pyrethroid widely used as an insecticide. The aim of our study was to determine the effect of a single exposure of female albino Swiss mice to DEL (at doses of $8.3 \mathrm{mg} / \mathrm{kg}, 20.75$ $\mathrm{mg} / \mathrm{kg}$, or $41.5 \mathrm{mg} / \mathrm{kg}$ ) on parameters of liver and kidney function and activities of antioxidant enzymes in these organs. The activity of alanine transaminase (ALT) in the blood sera of the experimental animals was not significantly elevated after exposure to DEL. Asparagine transaminase (AST) activity was significantly higher in the groups exposed to the moderate and the highest dose of DEL. The levels of creatinine in the blood sera of the experimental animals did not significantly differ among the groups. The activities of superoxide dismuthase (SOD) and glutathione peroxidase (GPx) were significantly reduced in the livers of mice exposed to the highest dose of DEL in comparison with controls. In the kidneys, however, the SOD and GPx activities were significantly elevated after exposure to the highest dose of DEL. In conclusion, DEL produces oxidative stress in the livers and, to a lesser degree, the kidneys of exposed animals.
\end{abstract}

Keywords: deltamethrin, antioxidant enzymes, oxidative stress

\section{Introduction}

Deltamethrin (DEL) is a synthetic pyrethroid. Pyrethroids are used as an insecticides [1], acaricides, and repellents [2]. They are used for public health improvement in malaria prevention actions [3]. Global climate change, with temperature increasing by 2 to $3^{\circ} \mathrm{C}$, makes the population living in endemic zones of malaria increase by 3 to $5 \%$ [4]. It also increases the risk of growing populations of insect pests destroying crops. Due to their environmental risk, organochlorine pesticides were withdrawn from the market (i.e., DDT in Poland in 1973). However, their traces are still present in arable soils in our country [5]. Another problem is obsolete pesticides posing a great environmental hazard [6]. Therefore, the use of pyrethroids,

*e-mail: barbaranieradkoiwanicka@umlub.pl which are less persistent in the environment, is expected to increase. Now up to $30 \%$ of all insecticides used in agriculture are pyrethroids. Poland has 13 registered pyrethroids. One of them is DEL. The current annual use of pyrethroids in Poland is estimated to be more than $80,000 \mathrm{~kg}$ used as an active ingredient [7].

Pyrethroids are neurotoxins acting on voltagegated sodium channels in neuron cell membranes [8, 9]. Intoxication produces paralysis and death of target organisms [10]. For over half a century it was believed that pyrethroids acted only via fast disregulation of the nervous system, without any significant cytotoxic effect. However, there is evidence that exposure to pyrethroids may produce neuron death in adult animals [11, 12], inhibition of nervous system development in rodent newborns [13-15], and damage to internal organs via toxic metabolites [16-18]. Recent studies show that pyrethroids 
impair kidney functioning [19], cause hepatic toxicity, change blood morphology, disrupt the endocrine system [20-22,], and lead to oxidative stress (OS) [24, 25].

Oxidative stress is an imbalance between reactive oxygen species (ROS) and antioxidants. The ROS can damage DNA, proteins, and lipids, and change a cell's metabolism, and affect gene expression and post-translational modifications of proteins, which accelerates ageing, neurodegeneration, and development of atherosclerosis, hypertension, type II diabetes, and cancer $[26,27]$. Superoxide dismuthase (SOD) and glutathione peroxidase (GPx) are antioxidant enzymes ubiquitous in living organisms acting as an endogenous defense against ROS [28, 29].

Chemically, pyrethroids are esters of alcohols and vinyl cyclopropane carboxylic acids. DEL is ((S)-alphacyano-3-phenoxybenzyl-91R,cis)-2,2-dimethyl-3-(2,2dibromovinyl)-cycloprpanecarboxylate. It is the most potent neurotoxic compound of the PYR group [30, 31]. It is used in the form of (cis)isomer [32]. DEL is rapidly absorbed after oral or intraperitoneal administration and quickly reaches its main target: voltage sensitive sodium channels in the central nervous system $[33,34]$. DEL is detoxified in mammals by hydrolysis of the ester bond by liver and plasma carboxyesterases to relatively non-toxic acidic and alcoholic moieties [8]. Cytochrome P450s in liver microsomes can catalyze aromatic hydroxylation of DEL [35]. These processes are followed by sulfate and glucuronide conjugation. Products of DEL metabolism are passed with urine. The metabolites of DEL most often detected in urine samples in human biomonitoring studies are cis-(2,2-dibromovinyl)-2,2-dimethylcyclopropane1-carboxylic acid $\left(\mathrm{Br}_{2} \mathrm{CA}\right)$, and 3-phenoxybenzoic acid (3-PBA) [36]. 3-PBA and $\mathrm{Br}_{2} \mathrm{CA}$ are detected in higher concentrations in urine samples from humans living in rural areas [37], but seem to be ubiquitous in men and women of all ages without job-related exposure to pesticides, suggesting wide exposure of the general population to DEL [36]. The current investigation aimed to explore the effect of single exposure to mice to DEL on parameters of liver and kidney function and activities of antioxidant enzymes in these organs.

\section{Materials and Methods}

All the experimental procedures were conducted with respect for the law regulations of the European Community and Poland. They were conducted at the Department of Hygiene, Medical University of Lublin, Poland. The Local Ethics Committee for Animal Experiments in Lublin approved the experiment (Opinion No. 4/2009, dated: 9 January 2009).

Non-gravid female albino Swiss mice weighing 18$24 \mathrm{~g}$ of approximately six weeks of age purchased from a licensed breeder (T. Górzkowski, Warsaw, Poland) were used in the study. All animals were given a sevenday acclimation period and maintained on a $12 \mathrm{hr}$ light/ dark cycle. Food and tap water were provided ad libitum. Temperature was maintained at $21 \pm 2^{\circ} \mathrm{C}$. The mice were randomly divided into four groups of eight animals each.

Deltamethrin was purchased from the manufacturer (Institute of Industrial Organic Chemistry, Annopol, Warsaw, Poland). As pyrethroids poorly dissolve in water, Tween 60 (poloxyethylene sorbitan monostearate) purchased from Laboratorium Reagenzien, Germany was used to prepare solutions in bi-distilled water.

On the first day of the experiment mice from each group were once injected intraperoitoneally:

- Group I (control) received saline (10 $\mathrm{ml}$ of saline per $1,000 \mathrm{~g}$ of mice body mass; a mouse of body mass 20 $\mathrm{g}$ received $0.2 \mathrm{ml}$ saline ip per injection).

- Group II received DEL at a dose of $8.3 \mathrm{mg} / \mathrm{kg}$ of body mass $(10 \mathrm{ml}$ of solution was prepared per $1,000 \mathrm{~g}$ of mice body mass; $0.1 \mathrm{ml}$ of Tween was used pr $10 \mathrm{ml}$ of solution; a mouse of body mass $20 \mathrm{~g}$ received $0.2 \mathrm{ml}$ solution ip per injection).

- Group III received DEL at a dose of $20.75 \mathrm{mg} / \mathrm{kg}$ of body mass.

- Group IV received DEL at a dose of $41.5 \mathrm{mg} / \mathrm{kg}$ of body mass.

On the second day mice were decapitated, and their blood samples were collected to clot in order to measure ALT and AST activity in the blood sera and creatinine concentration. Livers and kidneys were used to measure

Table 1. Effect of DEL on ALT, AST, and creatinine in the blood sera, SOD, and GPx activities in the livers and kidneys of experimental animals; $\mathrm{N}=8,{ }^{*} \mathrm{p}<0.05$ vs. control.

\begin{tabular}{|c|c|c|c|c|}
\hline & Control & DEL $8.3 \mathrm{mg} / \mathrm{kg}$ & DEL 20.75 mg/kg & DEL 41.5 mg/kg \\
\hline ALT (U/l) & $38 \pm 3$ & $40 \pm 4.7$ & $39.3 \pm 1.2$ & $43 \pm 8.5$ \\
\hline AST (U/1) & $170 \pm 5.8$ & $235 \pm 16.6$ & $307 \pm 13.6^{*}$ & $386.7 \pm 113.5^{*}$ \\
\hline $\begin{array}{c}\text { SOD activity in livers } \\
\text { (U/g of tissue) }\end{array}$ & $2,912.3 \pm 171$ & $2,337.3 \pm 187$ & $2,150 \pm 261^{*}$ & $2,126 \pm 156^{*}$ \\
\hline $\begin{array}{c}\text { GPx activity in livers } \\
\text { (U/g of tissue) }\end{array}$ & $34.4 \pm 13.3$ & $37.5 \pm 6.2$ & $22 \pm 4.4$ & $11 \pm 2.2^{*}$ \\
\hline Creatinine (mg\%) & $0.25 \pm 0.1$ & $0.2 \pm 0.1$ & $0.2 \pm 0.1$ & $0.3 \pm 0.1$ \\
\hline $\begin{array}{c}\text { SOD activity in kidneys } \\
\text { (U/g of tissue) }\end{array}$ & $910 \pm 55.7$ & $868 \pm 151.4$ & $918 \pm 227.5$ & $1,556 \pm 152^{*}$ \\
\hline $\begin{array}{c}\text { GPx activity in kidneys } \\
\text { (U/g of tissue) }\end{array}$ & $5.3 \pm 0.7$ & $26.7 \pm 3^{*}$ & $27.6 \pm 6.8^{*}$ & $30.3 \pm 3.5^{*}$ \\
\hline
\end{tabular}


SOD and GPx activities. The SOD activity was measured with the use of a RANSOD kit manufactured by Randox Laboratories Ltd., with a spectrophotometric method [38]. The livers were homogenized with an MPW-120 mechanical blender in a $0.1 \mathrm{M}$ buffer of Tris- $\mathrm{HCl}, 7.4 \mathrm{pH}$ ( $0.5 \mathrm{~g}$ of tissue per $5 \mathrm{ml}$ buffer). The homogenates were centrifuged for $15 \mathrm{~min}$ twice at 5,000 rpm. The supernatants were collected for SOD activity measurement.

The activity of GPx was measured with the use of a RANSEL kit manufactured by Randox Laboratories Ltd. Using the spectrophotometric method [39].

The results obtained were shown as means \pm SEM, and evaluated by one-way analysis of variance ANOVA followed by Dunnett's test. The $\mathrm{p}$ value $<0.05$ was considered statistically significant.

\section{Results}

The activity of ALT in the blood sera of the experimental animals was not significantly elevated after exposure to DEL (Table 1). The AST activity was significantly higher in the groups exposed to the moderate and the highest dose of DEL. The levels of creatinine in the blood sera did not significantly differ among the groups. The activities of SOD and GPx were significantly reduced in the livers of mice exposed to the highest dose of DEL in comparison with controls. In the kidneys, however, the SOD and GPx activities were significantly elevated after exposure to DEL.

\section{Discussion and Conclusion}

Pyrethroids are potent neurotoxins, as confirmed in our former studies $[40,41]$. In one of our previous experiments we found that DEL administered to mice at the dose of $16.6 \mathrm{mg} / \mathrm{kg}$ for 14 subsequent days increased urea concentrations, but did not affect the level of creatinine [19]. This time we aimed to find out if higher doses of DEL could impair liver and/or kidney function and produce oxidative stress in these organs.

Healthy organisms are able to combat oxidative stress with enzymatic (SOD and GPx) and non-enzymatic antioxidant systems. However, after exposure to sublethal doses of pesticides, which is an extreme oxidative challenge, the antioxidant system may become overwhelmed and fail [42].

The depletion of the antioxidant enzymes found in the livers in our study show that oxidative stress occurs in the liver after exposure to the highest dose of DEL. Our study showed a significant decrease in GPx and SOD activities in the livers of experimental animals exposed to the highest dose of DEL. However, ALT activities were not significantly elevated. The AST activities were significantly elevated in mice exposed to the moderate and highest doses of DEL. It is worth adding that AST is less specific for hepatic lesion, and it may be elevated in results of muscle or brain damage, too. This indicates that DEL produces mul- ti-organ damage. Dubey et al. reported significant hepatic oxidative stress and hepatic damage in rats exposed to DEL administered with fluoride [25]. The results of the experiment carried out by Galal et al. seem to confirm the theory that DEL produces oxidative stress, as they showed that exposure to DEL caused a significant increase in lipid peroxidation, nitric oxide concentration, and DNA fragmentation percentage, plus a significant reduction of total antioxidant capacity of DEL-treated groups of rats [43]. Other authors have demonstrated that pyrethroids produce oxidative stress in exposed cells, which leads to a reduction in concentration of thiol groups [44].

According to Popa-Wagner [45], in oxidative stress an up-regulation of genes coding antioxidant enzymes occurs. Glutathione peroxidases are enzymes containing selenium (Se). The activity of GPx in the cells may increase until an adequate supply of Se in the diet maximizes the enzyme activity [46]. Apparently, the metabolites od DEL (3-PBA and $\mathrm{Br}_{2} \mathrm{CA}$ ) do not pose a great risk to kidney functioning as creatinine concentrations in the blood sera were not elevated. The SOD and GPx activities in the kidneys were elevated, suggesting that the kidneys were able to neutralize the ROS species formed in response to intoxication with DEL.

In conclusion, DEL produces oxidative stress in the livers and, to a lesser degree, in the kidneys of exposed animals.

\section{References}

1. NAZIMEK T., WASAK M., ZGRAJKA W., TURSKI W.A. Content of transfluthrin in indoor air during the use of electro-vaporizers. Ann. Agric. Environ. Med. 18, 85, 2011.

2. CISAK E., WÓJCIK-FATLAA., ZAJĄC V., DUTKIEWICZ J. Repellents and acaricides as personal protection measures in the prevention of tick-borne diseases. Ann. Agric. Environ. Med. 19 (4), 625, 2012.

3. WHOPES Safety of pyrethroids for public health use. WHO Pesticide Evaluation Scheme. 2005.

4. SHUMAN E.K. Global climate change and infectious diseases. N. Engl. J. Med. 362 (12), 1061, 2010.

5. MALISZEWSKA-KORDYBACH B., SMERCZAK B., KLIMOWICZ-PAWLAS A. Evaluation of the status of contamination of arable soils In Poland with DDT and $\mathrm{HCH}$ residues; National and regional scales. Pol. J. Environ. Stud. 23 (1), 139, 2014.

6. KOCUR-BERA K., DUDZIŃSKA M. Spatial conditions of environmental risk posed by obsolete pesticides- case study of the „, Green Lungs of Poland” area. Pol. J. Environ. Stud.23 (3), 763, 2014.

7. Ministry of Agriculture and Rural Development - Report about Annual Pesticide Market Volume, 2011. Available from: www.bip.minrol.gov.pl (accessed 15.10.2014).

8. SODERLUND D.M., CLARK J.M., SHEETS L.P., MULLIN L.S., PICCIORILLO V.J., SARGENT D. Mechanisms of pyrethroid neurotoxicity: implications for cumulative risk assessment. Toxicology 171, 3, 2002.

9. RAY D.E., FORSHAW P.J. Pyrethroid insecticides; poisoning syndromes, synergies, and therapy. J. Toxicol. Clin .Toxicol. 38, 95, 2000.

10. DAVIES T.G., FIELD L.M., USHERWOOD P.N., 
WILLIAMSON M.S. DDT, pyrethrins, pyrethroids and insect sodium channels. IUBMB Life 59 (3), 151, 2007.

11. ABDEL-RAHMAN A., SHETTY A.K., ABU-DONIA M.B. Subchronic dermal application of N,N-diethyl m-toluamide (DEET) and permethrin to adult rats, alone or in combination, causes diffuse neuronal cell death and cytoskeletal abnormalities in the cerebral cortex in the hippocampus, and Purkinje neuron loss in the cerebellum. Exp. Neurol. 172, 153, 2001.

12. ABDEL-RAHMAN A., DECHKOVSKAIA A.M., GOLDSTEIN L.B., BULLMAN S.H., KHAN W., EL MASRY E.M. Neurological deficits induced by malathion, DEET, and permethrin, alone or in combination in adult rats. J. Toxicol. Environ. Health. A 67, 331, 2004.

13. CANTALAMESSA F. Acute toxicity of 2 pyrethroids, permethrin and cypermethrin in neonatal and adult rats. Arch. Toxicol., 67, 510, 1993.

14. PATRO N., PATRO I.K. Effects of deltamethrin on granule cell migration during postnatal development of rat cerebellum. Indian. Exp. Biol. 43, 158, 2005.

15. IMAMURA L., HASEGAWA H., KURASHINA K., MATSUNO T., TRUDA M. Neonatal exposure of newborn mice to pyrethroid (permethrin) represses activity-dependent c-Fos mRNA expression in cerebellum. Arch. Toxicol. 76, 392, 2002.

16. CASIDA J.E., UEDA K., GAUGHAN L.C., JAO L.T., SODERLUND D.M. Structure- biodegradability relationships in pyrethroid insecticides. Arch. Environ. Contam. Toxicol. 3, 491, 1975.

17. SODERLUND D.M., CASIDA J.E. Effects of pyrethroid structure on rates of hydrolysis and oxidation by mouse-liver microsomal-enzymes. Pestic. Biochem. Physiol. 7, 391, 1977.

18. SHONO T., OHSAWA K., CASIDA J.E. Metabolism of trans-permethrin and cis-permethrin, trans- cypermethrin, and cis-cypermethrin, and decamethrin by microsomal enzymes. J. Agric. Food Chem. 27, 316, 1979.

19. BORZECKI A., NIERADKO-IWANICKA B., PASTERNAK K., BORZĘCKA $H$. The neprotoxicity evaluation of deltamethrine in experimental animals. Pol. J. Environ. Stud. 14 (II), 461, 2005.

20. MEEKER J.D., BARR D.B., HAUSER R. Pyrethroid insecticide metabolites are associated with serum hormone levels in adult men. Reprod. Toxicol. 27, 155, 2009.

21. ORTON F., ROSIVATZ E., SCHOLZE M., KORTENKAMP A. Widely used pesticideswith previously unknown endocrine activity revealed as in vitro antiandrogens. Environ. Health. Perspect. 119, 794, 2011.

22. JIN Y., LIU J., WANG L., CHEN R., ZHOU C., YANG Y., LIU W., FU Z. Permethrin exposure during puberty has the potential to enantioselectively induce reproductive toxicity in mice. Environ. Int. 42, 144, 2012.

23. VELISEK J., SVOBODOVA Z., PIACKOVA V. Effects of acute exposure to bifenthrin on some haematological,bioochamical and hisopathological parameters of rainbow trout (Oncorhynchus mykiss). Veterinarni Medicina 54 (3), 131, 2009.

24. DAR M.A., KHAN A.M., RAINA R., VERMA P.K., SULTANA M. Effect of repeated oral administration of bifenthrin on lipid peroxidation and anti-oxidant parameters in Wistar rats. Bull. Environ. Contam. Toxicol. 91 (1), 125, 2013.

25. DUBEY N., KHAN A.M., RAIN A.R. Sub-acute deltamethrin and fluoride toxicity induced hepatic oxidative stress and biochemical alternations in rats. Bull. Environ. Contam. Toxicol. 91 (3), 334, 2013.

26. SIWEK M., SOWA-KUĆMA M., DUDEK D., STYCZEŃ
K., SZEWCZYK B., KOTARSKA ., MISZTAL P., PILC A., WOLAK M., NOWAK G. Oxidative stress markers in affective disorders. Pharm. Rep. 65, 1558, 2013.

27. LORENC-KOCI E., CZRNECKA A. Role of nitric oxide in the regulation of motor function. An overview of behavioral, biochemical and histological studies in animal models. Pharm. Rep. 65, 1043, 2013.

28. MUSIK I., KIEŁCZYKOWSKA M., KOCOT J. Comparison of the influence of selenium supplementation in organic and inorganic forms on oxidant/antioxidant balance in rat lungs. Bull. Vet. Inst. Pulawy 57, 449, 2013.

29. PERRY J.J.P., SHIN D.S., GETZOFF E.D., TAINER J.A. The structural biochemistry of superoxide dismuthases. Biochim. Biophys. Acta 1804 (2), 245, 2010.

30. PHAM H.C., NAVARRO-DELMASURE C., PHAM H.C., CLAVEL P., VAN HAVERBEKE G., CHEAV S.L. Toxicological studies of deltamethrin. Int. J. Tissue. React. 6, 127, 1984.

31. RUZO LO, CASIDA JE. Metabolism and toxicology of pyrethroids with dihalovinyl substitutes. Environ. Health. Perspect. 21, 285, 1977.

32. ELLIOTT M., FARNHAM A.W., JANES N.F., NEEDHAM P.H., PULMAN D.A. Synthetic insecticide with a new order of activity. Nature 248, 710, 1974.

33. ANADÓN A., MARTINEZ- LARRAŇAGA M.R., FERNANDEZ-CRUZ M., DIAZ M.J., FERNANDEZ M.C., MARTINEZ M.A. Toxokinetics of deltamethrin and its 4'-HO-metabolite in the rat. Toxicol. Appl. Pharmacol. 141 (1), 8, 1996.

34. RICKARD J., BRODIE M.E. Correlation of blood and brain levels of the neurotoxin pyrethroid deltamethin with the onset of symptoms in rats. Pestic. Biochem. Physiol. 23, 143,1985

35. ANAND S.S., BRUCKNER J.V., HAINES W.T., MURALIDHARA S., FISHER J.W, PADILLA S. Characterization of deltamethrin metabolism by rat plasma and liver microsomes. Toxicol. Appl .Parmacol. 212, 156, 2006.

36. WIELGOMAS B., NAHORSKI W., CZARNOWSKI W. Urinary concentrations of pyrethroid metabolites in the convenience sample of an urban population of Northern Poland. Int. J. Hyg. Environ. Health. 216, 295, 2013.

37. WIELGOMAS B., PISKUNOWICZ M. Biomonitoring of pyrethroid exposure among rural and urban populations in northern Poland .Chemosphere 93, 2547, 2013

38. ARTHUR J.R., BOYNE R. Superoxide dismutase and glutathione peroxidase activities in neutrophils from selenium deficient and copper deficient cattle. Life Sci. 36, $1569,1985$.

39. PAGLIA D.E., VALENTINE W.N. Studies on the quantitative and qualitative characterization of erythrocyte glutathione peroxidase. J. Lab. Clin. Med., 70, 158, 1967.

40. NIERADKO-IWANICKA B., BORZĘCKI A. Betacyfluthrin's influence on memory processes in mice after transient oligemic brain hypoxia. Polish J. Environ. Stud. 13 (II), 350, 2004.

41. NIERADKO-IWANICKA B., KALINIWSKI P., BORZECKI A. Effect of deltamethrin on memory processes in mice after transient brain oligemia. Polish J. Environ. Stud. 15 (2b), 501, 2006.

42. SAXENA R., GARG P. Vitamin E provides protection against in vitro oxidative stress due to pesticide (Chlorpyrifos and Endosulfan) in goat RBC. Bull. Biosci. 1, 1, 2010.

43. GALAL M.K., KHALAF A.A., OGALY H.A., IBRAHIM M.A. Multimechanistic neuroprotective effect of vitamin $\mathrm{E}$ against deltamethrin induced brain toxicity. Toxicol. 
Rep. 2014 http://dx.doi.org/10.1016.j.toxrep.2014.09.008 (accessed 07.10 2014).

44. KRZEPIŁKO A. Effect of selected pyrethroids on concentration of thiol groups in Saccharomyces cerevisiae yeast cell extract. Proceedings of ECCOpole, 2 (2), 451, 2008.

45. POPA-WAGNER A. Alzheimer's disease pathological factors in ischemic aged brain. In: Pluta R. (Red.) Ischemia- reperfusion pathways in Alzheimer's disease. USA, Nova Science Publishers, Inc., 51, 2007.

46. MUSIK I., KIEŁCZYKOWSKA M., KOCOT J. Comparison of the influence of selenium supplementation in organic and inorganic forms on oxidant/antioxidant balance in rat lungs. Bull. Vet. Inst. Pulawy 57, 449, 2013. 